\title{
Epidemiology of leprosy indicators in the Municipality of Crato, Ceará
}

\author{
Epidemiologia de indicadores de hanseníase no Município de Crato, Ceará \\ Epidemiología de indicadores de lepra en la Ciudad de Crato, Ceará
}

Received: 03/09/2021 | Reviewed: 03/16/2021 | Accept: 03/23/2021 | Published: 03/30/2021

Angélica Rodrigues de Souza Costa ORCID: https://orcid.org/0000-0001-5872-9492 Federal University of Cariri, Brazil

E-mail: angelicarodrigues.pb@gmail.com

Kleber Ribeiro Fidelis

ORCID: https://orcid.org/0000-0002-2507-1468

Federal University of Pernambuco, Brazil E-mail: kleberfidelis0@gmail.com

Maraiza Gregorio de Oliveira

ORCID: https://orcid.org/0000-0002-2855-641X

Regional University of Cariri, Brazil

E-mail: maraaiza0104@hotmail.com

Luciano Temoteo dos Santos

ORCID: https://orcid.org/0000-0002-9215-6832 Federal University of Cariri, Brazil

E-mail: luciano.temoteosantos@gmail.com

Marcos Aurélio Figueiredo dos Santos ORCID: https://orcid.org/0000-0002-3409-5242 Regional University of Cariri, Brazil E-mail: marcos.figueiredo@urca.br

Yedda Maria Lobo Soares de Matos ORCID: https://orcid.org/0000-0002-1837-2844

Regional University of Cariri, Brazil E-mail: yedda.lobo@urca.br João Cruz Neto

ORCID: https://orcid.org/0000-0002-0972-2988 Regional University of Cariri, Brazil E-mail: enfjcncruz@gmail.com

Talina Guedes Ribeiro

ORCID: https://orcid.org/0000-0001-5801-6679 Regional University of Cariri, Brazil E-mail: thalinaguedes@gmail.com Diane Sales Vieira

ORCID: https://orcid.org/0000-0003-3228-0791 Regional University of Cariri, Brazil E-mail: dianesales.enf@hotmail.com

Cicera Rejania da Silva Braga ORCID: https://orcid.org/0000-0002-6214-9447 Regional University of Cariri, Brazil E-mail: rejania.braga@hotmail.com

Milena Roberta Freire da Silva

ORCID: https://orcid.org/0000-0003-0203-4506

Federal University of Pernambuco, Brazil

E-mail: milena.freire@ufpe.br

Renato Juciano Ferreira

ORCID: https://orcid.org/0000-0002-9786-2226 Regional University of Cariri, Brazil E-mail: renatojuciano@hotmail.com

Maria Aurea Soares de Oliveira ORCID: https://orcid.org/0000-0002-8596-9157 Regional University of Cariri, Brazil E-mail: aureasoares16@hotmail.com

Antonio Silva Candido

ORCID: https://orcid.org/0000-0002-2246-8478 Regional University of Cariri, Brazil E-mail: tonhocandido31@gmail.com

Francisco Matheus de Andrade Arrais ORCID: https://orcid.org/0000-0001-9423-610X 


\author{
Antonio Rafael da Silva \\ ORCID: https://orcid.org/0000-0003-4769-1454 \\ Regional University of Cariri, Brazil \\ E-mail: raphaelsilvha@gmail.com \\ Conceição Taís de Araújo Pereira \\ ORCID: https://orcid.org/0000-0002-9805-8969 \\ Regional University of Cariri, Brazil \\ E-mail: araujotais.bio11@gmail.com \\ Raimundo Samuel Leite Sampaio \\ ORCID: https://orcid.org/0000-0002-1902-3064 \\ Regional University of Cariri, Brazil \\ E-mail: samsampaio@hotmail.com \\ Viviane Bezerra da Silva \\ ORCID: https://orcid.org/ 0000-0003-0581-2609 \\ Federal University of Pernambuco, Brazil \\ E-mail: viviane_silvabezerra@hotmail.com \\ Bárbara Elvira Meneses de Brito Nunes \\ ORCID: https://orcid.org/0000-0003-3625-6879 \\ University Center Doutor Leão Sampaio, Brazil \\ E-mail: barbara_crato@hotmail.com \\ Francisco Diego Pereira \\ ORCID: https://orcid.org/0000-0002-4816-3381 \\ Faculty of Juazeiro do Norte, Brazil \\ E-mail: diego.vilar.pereira@gmail.com \\ José Weverton Almeida-Bezerra \\ ORCID: https://orcid.org/0000-0002-0966-9750 \\ Federal University of Pernambuco, Brazil \\ E-mail: weverton.almeida@urca.br
}

\begin{abstract}
Leprosy is a comorbidity that affects numerous people all over the world, which is characterized by its affinity for the skin and peripheral nerves. The objective of this research was to carry out an analysis of the epidemiological aspects and temporal trends of leprosy indicators in the municipality of Crato. To achieve these objectives, a qualitative and quantitative research was carried out, based on data from the Notifiable Diseases Information System. Between 2007 and 2017, 477 new cases of leprosy were reported in the municipality of Crato, highlighting the year 2012 with the highest number of new cases of the disease, with emphasis on the incidence of cases in men (59.1\%), while in women it was $40.8 \%$. Of these, with a predominance of the age group between 50 to 59 years (20.7\%), followed by 60 to 69 years $(18.6 \%)$. According to the results proposed by this research, it can be observed that, in the last few years, there has been a significant reduction in the number of cases. To maintain this index, political commitment and quality health services for effect the service of secondary care in the municipality.
\end{abstract}

Keywords: Mycobacterium leprae; Crato; SINAN; Bacillus.

\title{
Resumo
}

A hanseníase é uma comorbidade que afeta inúmeras pessoas em todo o mundo, caracterizada por sua afinidade pela pele e nervos periféricos. $\mathrm{O}$ objetivo desta pesquisa foi realizar uma análise dos aspectos epidemiológicos e tendências temporais dos indicadores de hanseníase no município do Crato. Para atingir esses objetivos, foi realizada uma pesquisa qualitativa e quantitativa, com base nos dados do Sistema de Informação de Agravos de Notificação. Entre 2007 e 2017, foram notificados 477 casos novos de hanseníase no município do Crato, destacando-se o ano de 2012 com maior número de casos novos da doença, com destaque para a incidência de casos em homens $(59,1 \%)$, enquanto em mulheres era $40,8 \%$. Destes, com predomínio da faixa etária entre 50 a 59 anos $(20,7 \%)$, seguida de 60 a 69 anos $(18,6 \%)$. De acordo com os resultados propostos por esta pesquisa, pode-se observar que, nos últimos anos, houve uma redução significativa no número de casos. Para manter esse índice, há compromisso político e serviços de saúde de qualidade para efetivar o atendimento da atenção secundária no município.

Palavras-chave: Mycobacterium leprae; Crato; SINAN; Bacilo.

\section{Resumen}

La lepra es una comorbilidad que afecta a numerosas personas en todo el mundo, que se caracteriza por su afinidad por la piel y los nervios periféricos. El objetivo de esta investigación fue realizar un análisis de los aspectos epidemiológicos y tendencias temporales de los indicadores de lepra en el municipio de Crato. Para lograr estos objetivos, se realizó una investigación cualitativa y cuantitativa, basada en datos del Sistema de Información de Enfermedades Notificables. Entre 2007 y 2017 se reportaron 477 nuevos casos de lepra en el municipio de Crato, destacándose el año 2012 con mayor número de casos nuevos de la enfermedad, con énfasis en la incidencia de casos en hombres $(59,1 \%)$, mientras que en mujeres fue del 40,8\%. De estos, con predominio del grupo de edad de 50 a 59 años (20,7\%), seguido de 60 a 69 años (18,6\%). De acuerdo con los resultados propuestos por esta investigación, se puede observar que, en los últimos años, se ha producido una reducción significativa en el número de casos. Mantener 
este índice, compromiso político y servicios de salud de calidad para efectuar el servicio de atención secundaria en el municipio.

Palabras clave: Mycobacterium leprae; Crato; SINAN; Bacilo.

\section{Introduction}

Leprosy is a tropical, infectious and chronic disease, which has Mycobacterium leprae as an etiological agent, a mandatory intracellular parasite characterized by affinity for the skin and peripheral nerves (Fischer, 2017). The disease can cause dermatological and neurological injuries, physical disabilities and deformities (Mizoguti et al., 2015; WHO, 2017). The clinical forms of leprosy vary according to the number of lesions and their distribution, the presence of bacilli and the severity of the disease, classified as: undetermined, tuberculoid, dimorphic and virchowian (Ramos et al., 2020).

Since the year 2000, the appointment of leprosy as a "danger" to public health has been eliminated in all countries, when the reduction in the prevalence rate of one case per 10,000 inhabitants has been achieved (Brasil, 2018). However, due to the severity of the disease and related disabilities, leprosy is still considered an important public health problem, with monitoring measures in many countries, especially those in development that have high endemic outbreaks, such as Brazil (Brasil, 2017).

According to the World Health Organization (WHO), in 2017, 210,671 new cases of leprosy occurred in the world, corresponding to an average detection rate of 2.8 per 100,000 inhabitants. In Brazil, this year saw 26,875 new cases, which represents a detection rate of 12.94/100,000 inhabitants (WHO, 2018). Brazil is classified as a country with a high burden of the disease (according to WHO parameters), occupying the first place in terms of prevalence in the world, and second in number of cases detected annually, just after India (WHO, 2017; Brasil, 2018).

In Brazil, although the prevalence of the disease has decreased a lot in the last decades, the detection rate has not been effectively reduced (Fernandes et al., 2020). This indicates the need for the continuous commitment and organized effort of the entire basic health network aiming at control, monitoring and research to face the disease (WHO, 2019). In the last decades, the Brazilian government has been joining efforts in order to reduce the impact of the disease, however, in the Northeast, North and Center-West regions, epidemiological indicators indicate that the disease is far from being eliminated as a public health problem (Souza et al., 2017; Brasil, 2018). According to the Ministry of Health (MS), the state of Ceará stands out among the states of the Northeast, occupying the fourth position with the highest detection coefficient and the sixth in Brazil (Brasil, 2017b; Brasil, 2018).

Considering that the analysis of epidemiological data of patients with the disease, allows, among other aspects, to evaluate the efficiency of preventive measures, the reduction of its prevalence, the interruption of the transmission chain, the monitoring of the behavior patterns of the disease and the prevention of physical disabilities (Ramos et al., 2020). In this context, this study aims to analyze the epidemiological patterns and time trends of leprosy indicators in the municipality of Crato, Ceará, from 2007 to 2017.

\section{Materials and Methods}

The research consisted of a qualitative and quantitative study, which was based on the survey of leprosy cases from 2007 to 2017 in the municipality of Crato-CE, establishing relationships between the variables and the factors related to their prevalence. The study was carried out in the city of Crato, located in the south of Ceará in the so-called Cariri region. According to IBGE (2016) the city has an estimated population of 129,662 inhabitants spread over an area of $1,176.467 \mathrm{~km}^{2}$. It has a microclimate classified as Tropical Hot Semi-arid Brando and Tropical Hot Sub humid, with an average temperature of $24^{\circ} \mathrm{C}$ to $26^{\circ} \mathrm{C}$ and an average annual rainfall of $1,090.9 \mathrm{~mm}$. 
In the present study, the total number of leprosy cases per year, sex and age group of patients between the years 2007 and 2017 in the municipality of Crato-CE were analyzed, as well as the level of education of the population served. The number of cases was determined based on the analysis of data obtained from the Notifiable Diseases Information System SINAN. Data collection for the study was carried out in April 2017. For this purpose, patients with a diagnosis of leprosy treated at posts and hospitals in the municipality were included. From the information collected, a spreadsheet was prepared with the data and profiles of people who were diagnosed with the disease, and the number of cases in the municipality. The study was carried out in accordance with the ethical and legal recommendations contained in CNS Resolution 196/96. It should also be noted that this research did not harm the verified subjects as it was an investigation through data review, maintaining the confidentiality of their names and without the need for any organic collection.

\section{Results and Discussion}

Between the years 2007 and 2017, 477 new cases of leprosy were reported in the municipality of Crato-Ceará, with the year 2012 having the highest number of new cases of the disease. It can also be observed that there has been a progressive decrease in the number of leprosy cases over the years (Figure 1), possibly due to the efforts made for early diagnosis.

Figure 1: Number of new leprosy cases registered in the municipality of Crato - CE in the years 2007 to 2017.

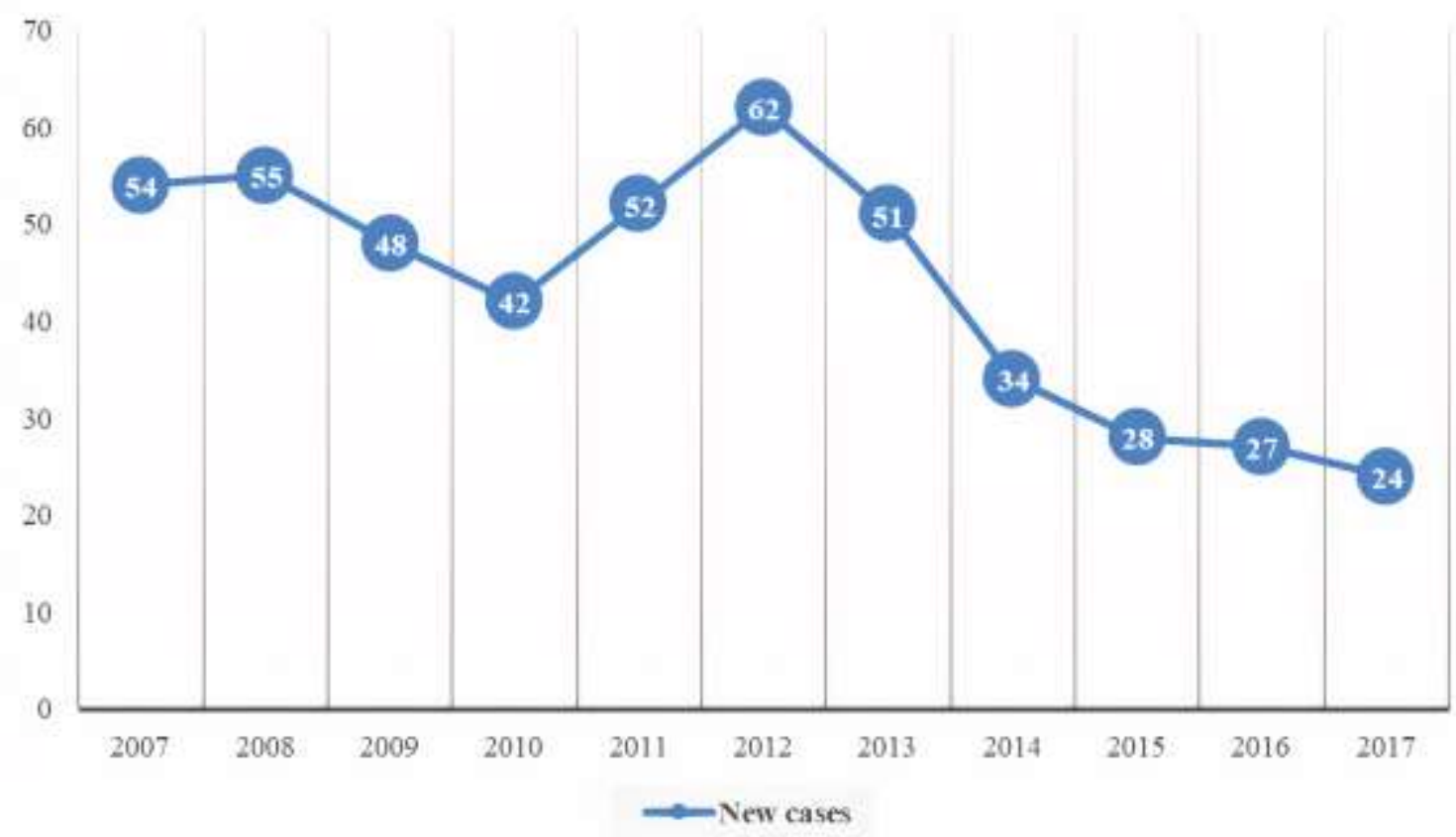

Source: Authors (2020).

The highest incidence of cases occurred in men, totaling 282 patients (59.1\%), while 195 (40.8\%) cases were reported in women (Figure 2). The data point to a greater number of cases in men, this statement, evidenced by other previous studies that observed higher rates of the disease among men (Monteiro et al., 2013; Ramos et al., 2013; Santos et al., 2020).

According to Lana et al., (2008), the higher occurrence of the disease in males may be associated with less access to health services, as these offer more programs aimed at women's health, as well as the lesser concern of men in relation to the body and aesthetics, contributing to the delay in diagnosis. 
Figure 2: Number of leprosy cases by sex reported in the years 2007 to 2017 in the municipality of Crato-CE.

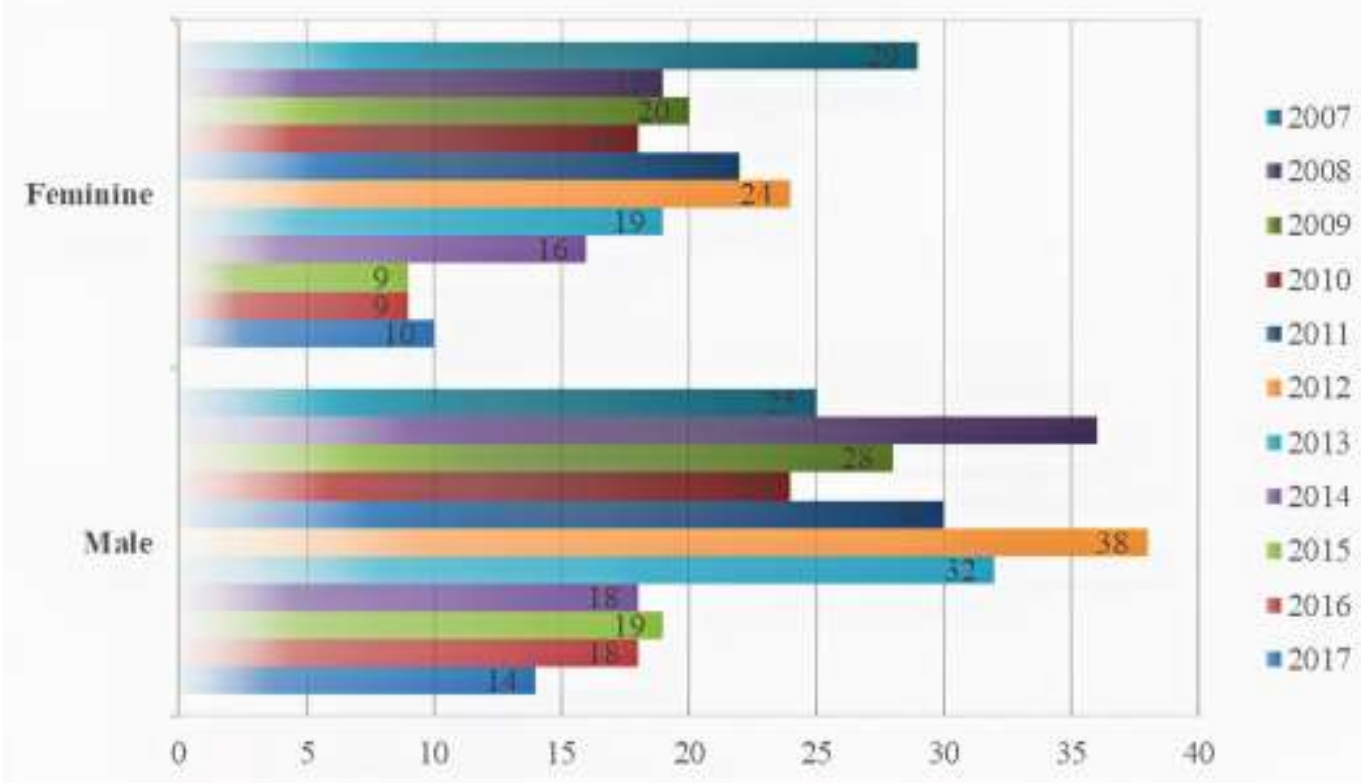

Source: Authors (2020).

In Figure 3, it is observed that the largest number of cases between the years 2007 and 2017 occurred between 50 and 59 years old $(20.7 \%$; 99), followed by the age group from 60 to 69 years old $(18.6 \%$; 89$)$. The smallest number of cases was registered in the age group from 1 to 4 years old, corresponding to $0.41 \%$ of the total in the period. Similar results were also obtained by Lira et al. (2019), who observed a higher incidence of the disease in the age group between 50 and 59 years for $19 \%$ of cases in the year 2017.

Figure 3: Age range of leprosy patients in the municipality of Crato-CE, between the years 2007 to 2017.

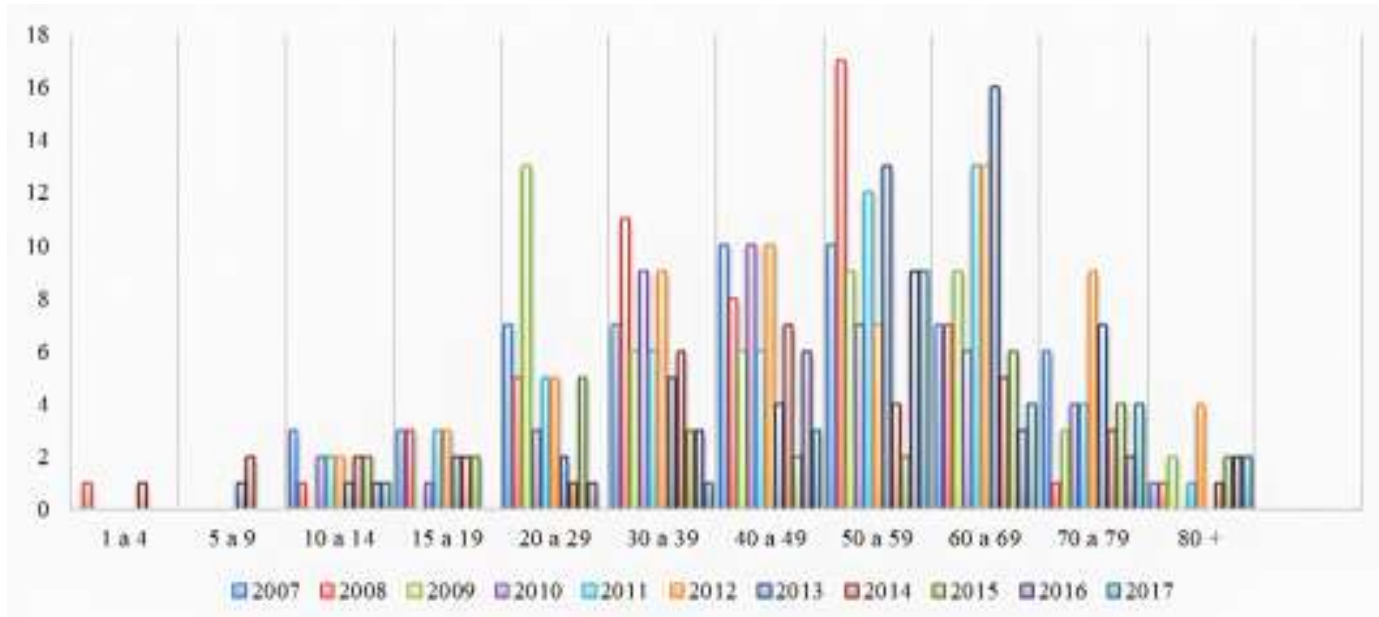

Source: Authors (2020).

According to data from the Ministry of Health, leprosy can affect people of all ages, of both sexes, however, it rarely affects children, while the highest incidence of the disease occurs in adult males, in most regions of the world (Brasil, 2018). The appearance of the disease in the person infected with the bacillus, and its different clinical manifestations, depend, among other factors, on the parasite / host relationship and can occur after a long incubation period, which varies from 2 to 7 years 
(Talhari et al, 2006). Therefore, when young adults show the first dermal and / or neural signs and symptoms, they were probably infected several years ago and eventually already have the bacilliferous and potentially disabling forms of leprosy (Brasil, 2018).

Figure 4 shows that only 2 people $(0.41 \%)$ of the 477 diagnosed with leprosy in the years 2007 to 2017 have completed higher education, 3 people $(0.62 \%)$ have completed high school and $17(3.56 \%)$ have completed elementary school. It was found that the majority of the carriers did not report their level of education, which corresponded to $7.33 \%$ of the carriers, followed by the people who completed the 4th grade of elementary school (5.66\%) and the people who had between Incomplete 1 st to 4 th grade of elementary school (5.45\%). 15 people (3.14\%) reported being illiterate, 25 people (5.24\%) had between the 5th and 8th grades of elementary school and 7 people (1.46\%) had incomplete high school. Similar results were evidenced by Dias et al. (2013), who showed in their studies that a significant portion of individuals with leprosy have low education.

Figure 4: Schooling of leprosy patients in the municipality of Crato-CE, 2007 to 2017.

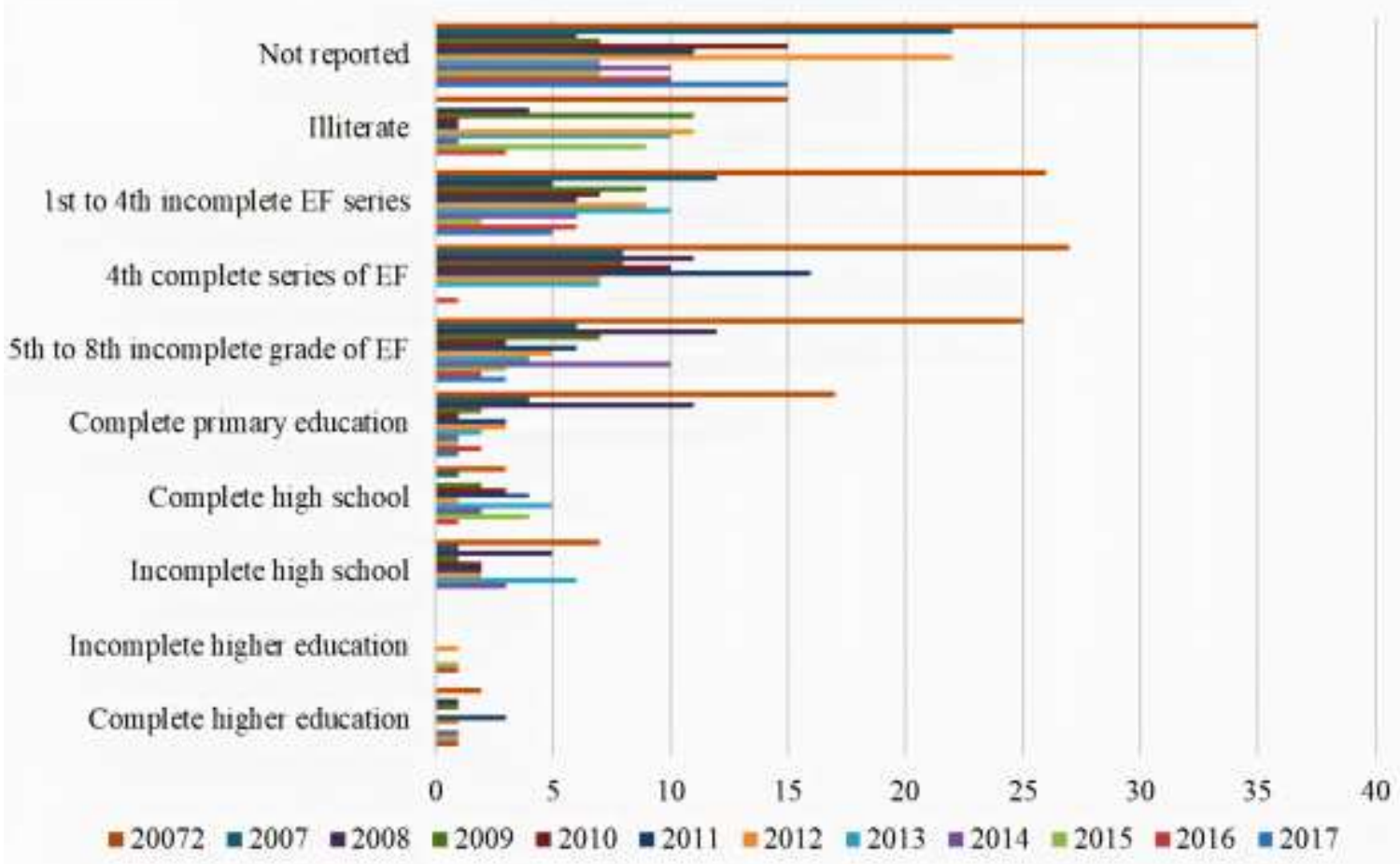

Source: Authors (2020).

According to Ramos et al. (2013), in relation to the social aspects of individuals diagnosed with leprosy, about $60 \%$ have a low level of education. These data were also observed in the municipality of Crato, Ceará, in this sense, it was demonstrated that leprosy patients have eight or less years of study, corroborating the findings of Amaral and Lana (2008) in the region of Vale do Jequitinhonha - Minas Gerais.

In general, the low level of education of leprosy patients can lead to little understanding and understanding of the factors involved with the disease, the length of treatment and health-related attitudes. In the initial stage of the disease, if the signs and symptoms of the disease are not recognized, it will not only cause physical disabilities and deformities, but also lead to the spread/transmission of the disease (Leano et al., 2019). Thus, it is important to understand the importance of health education, as it is through this that individuals will be made aware of the first signs of leprosy, the need for early diagnosis and 
prevention of the disease. Educational practice needs to break with socio-cultural paradigms, so that a new concept of the disease is rebuilt, eliminating the fear and prejudice present in the collective imagination (Santana et al., 2008; Monteiro et al., 2018).

Thus, it is necessary to understand that disease prevention actions must occur in parallel with control measures. Thus, the prevalence of the disease will be reduced by associating with early detection and the correct use of medicines, non-drug interventions, such as frequent neural monitoring and health education (Gonçalves, et al., 2008; Boigny et al., 2020).

\section{Conclusion}

The control of leprosy communicants has received little attention in the historical process of this disease in Brazil, which despite the great therapeutic advances resulting from it, still has a high proportion of cases with a degree of disability at the time of diagnosis, indicating the need for improvement in early detection. However, from the results proposed by this research, it can be seen that, in recent years, there has been a significant reduction in the number of leprosy cases in the population studied since 2013. In order to maintain this index, political commitment and quality health services are essential to carry out the secondary care service in the municipality, with awareness campaigns, early and effective treatment. Treatments and supports should be maintained, improving the quality of services more and more to support and sustain the essential actions of leprosy control, since it is a chronic infectious disease.

\section{Acknowledgments}

We thank the Unified Health System of Brazil and the Regional University of Cariri.

\section{References}

Amaral, E. P., \& Lana, F. C. F. (2008). Análise espacial da Hanseníase na microrregião de Almenara, MG, Brasil. Revista Brasileira de Enfermagem, 61(SPE), 701-707.

Boigny, R. N., Souza, E. A. D., Ferreira, A. F., Cruz, J. R., García, G. S. M., Prado, N. M. B. D. L., \& Ramos Júnior, A. N. (2020). Falhas operacionais no controle da hanseníase em redes de convívio domiciliar com sobreposição de casos em áreas endêmicas no Brasil. Epidemiologia e Serviços de Saúde, 29, 114.

Dias, J. L., Godoy, G. M. S., Aguiar, R. S., \& Gomes, G. P. L. A. (2013). Características determinantes entre portadores de hanseníase em uma área hiperendêmica. Revista de Atenção à Saúde, 11(38), 32-37.

Fernandes, T. R. M. D. O., Pereira, A. D. A., Cardoso, L. S., Alves Filho, V. P., Rezende Junior, L. S. N. D., \& Souza, C. D. F. D. (2020). The hidden prevalence of leprosy: a comparative study between two Brazilian cities. Revista da Associação Médica Brasileira, 66(10), 1338-1343.

Fischer, M. (2017). Leprosy-an overview of clinical features, diagnosis, and treatment. JDDG: Journal der Deutschen Dermatologischen Gesellschaft, 15(8), 801-827.

Gonçalves, S. D., Sampaio, R. F., \& Antunes, C. M. D. F. (2008). Ocorrência de neurite em pacientes com hanseníase: análise de sobrevida e fatores preditivos. Revista da Sociedade Brasileira de Medicina Tropical, 41 (5), 464-469.

Lana, F. C. F., Amaral, E. P., Lanza, F. M., Lima, P. L., Carvalho, A. C. N. D., \& Diniz, L. G. (2007). Hanseníase em menores de 15 anos no Vale do Jequitinhonha, Minas Gerais, Brasil. Revista Brasileira de Enfermagem, 60(6), 696-700.

Leano, H. A. D. M., Araújo, K. M. D. F. A., Bueno, I. D. C., Niitsuma, E. N. A., \& Lana, F. C. F. (2019). Factores socioeconómicos relacionados con la lepra: revisión integrativa de la literatura. Revista Brasileira de Enfermagem, 72(5), 1405-1415.

Lira, T. B., Rocha, F. C. V., Sá Martins, D. M., Lopes, T. P., Sousa Oliveira, K. M., Santos, B. L., \& Lemos, N. A. F. (2019). Hanseníase no Piauí: uma investigação epidemiológica. Revista Eletrônica Acervo Saúde, 1(24), e499-e499.

Marciano, L. H. S. C., Prado, R. B. R., Quaggio, C. M. D. P., \& Nardi, S. M. T. (2008). Proposta pedagógica para aprimorar os conceitos básicos em Hanseníase: álbum seriado como um recurso no processo de orientação. Hansenologia Internationalis, 33(2), $17-24$.

Ministério da Saúde (2018). Caracterização da Situação epidemiológica da hanseníase e diferenças por sexo, Brasil, 2012- 2016. Boletim epidemiológico, 22, $1-55$.

Ministério da Saúde (BR). Secretaria de Vigilância em Saúde. Departamento de Vigilância das Doenças Transmissíveis Coordenação Geral de Hanseníase e Doenças em Eliminação. Banco de dados do programa: 2017(SINAN Nacional). Brasília (DF), $2017 \mathrm{~b}$. 
Research, Society and Development, v. 10, n. 4, e5010413720, 2021

(CC BY 4.0) | ISSN 2525-3409 | DOI: http://dx.doi.org/10.33448/rsd-v10i4.13720

Ministério da Saúde. Secretaria de Vigilância em Saúde (2017). Coordenação-Geral de Desenvolvimento da Epidemiologia em Serviços. Guia de Vigilância em Saúde. 222 p.

Mizoguti D. F., Hungria E. M., Freitas A. A., Oliveira R. M., Cardoso L. P., \& Costa M. B., (2015). Pacientes com hanseníase multibacilar com anticorpos séricos elevados e persistentes para hanseníase IDRI diagnostic-1 / LID-1: maior suscetibilidade para desenvolver reações do tipo 2. Mem Inst Oswaldo Cruz. $110,914-920$.

Monteiro, B. R., Ataíde, C. A. V., Assis Silva, C. J., Neres, J. N. S., Medeiros, E. R., \& Simpson, C. A. (2018). Educação em saúde para a hanseníase: experiência da enfermagem. Saúde (Santa Maria), 44(1), 1-5.

Monteiro, L. D., Alencar, C. H. M. D., Barbosa, J. C., Braga, K. P., Castro, M. D. D., \& Heukelbach, J. (2013). Incapacidades físicas en personas afectadas por la hanseniasis en el período post alta de la poliquimioterapia en un municipio en el norte de Brasil. Caderno de Saúde Pública, 29(5), 909-920.

OMS - Organização Mundial da Saúde. Global leprosy update, 2017: reducing the disease burden due to leprosy. The Weekly Epidemiological Record, 93, pp. $445-456$.

Organização Mundial da Saúde (OMS). Atualização global sobre hanseníase, 2017: reduzindo a carga de doenças devido à hanseníase. Registro epidemiológico semanal, 35 , pp. 444-456.

Ramos, A. R. D. S., Ferreira, S. M. B., \& Ignott, E. (2013). Óbitos por hanseníase como causa básica em residentes no estado de Mato Grosso, Brasil, no período de 2000 a 2007. Epidemiologia e Serviços de Saúde, 22(2), 273-284.

Ramos, B. S., Marisco, G., \& Costa, D. J. (2020). Perfil epidemiológico e sociodemográfico dos pacientes com hanseníase, no período de 2001 a 2017 , em Vitória da Conquista, Bahia, Brasil. Revista Saúde.Com, 16, 1710 - 1720.

Santos, Á. N., Costa, A. K. A. N., Souza, J. É. R. D., Alves, K. A. N., Oliveira, K. P. M. M. D., \& Pereira, Z. B. (2020). Perfil epidemiológico e tendência da hanseníase em menores de 15 anos. Revista da Escola de Enfermagem da USP, 54, 1-8.

Secretaria de Vigilância em Saúde. Ministério da Saúde. (2018). Caracterização da situação epidemiológica da hanseníase e diferenças por sexo, Brasil, 20122016. Boletim Epidemiológico, 49, 1-12.

Souza, C. D. F., Oliveira Fernandes, T. R. M., Matos, T. S., Ribeiro Filho, J. M., Almeida, G. K. A., Lima, J. C. B., \& Oliveira, D. J. (2017). Grau de incapacidade física na população idosa afetada pela hanseníase no estado da Bahia, Brasil. Revista Acta Fisiatrica, 24(1), $27-32$.

Talhari, S, Neves, R. G., Penna, G. O., Oliveira, M. L. V., Hanseníase. (4a ed.), Gráfica Tropical; 2006.

WHO. Weekly epidemiological record. global leprosy update, 2018: moving towards a leprosy-free world. Nova Deli: World Health Organisation. 2019: [s.n.]. <http://www.who.int/wer>. 